Volume 3 Issue 1, March 2019: pp. 1-15. Copyright (c) 2019 HOLREV. Faculty of Law, Halu Oleo University, Kendari, Southeast Sulawesi, Indonesia. ISSN: 2548-1762 | e-ISSN: 2548-1754. Open Access at: http://ojs.uho.ac.id/index.php/holrev/

Halu Oleo Law Review is licensed under a Creative Commons Attribution 4.0 International License, which permits unrestricted use, distribution, and reproduction in any medium, provided the original work is properly cited.

\title{
Kewajiban Corporate Social Responsibility (CSR) oleh Korporasi yang Berimplikasi Tindak Pidana Korupsi
}

\author{
The Obligation for Corporate Social Responsibility (CSR) \\ Toward the Corporation Implicated Corruption
}

\author{
Muhammad Dahlan Moga \\ Ketua Dewan Pimpinan Cabang Perhimpunan Advokat Indonesia \\ (PERADI) Kendari \\ E-mail: dahlan.lawoffice@gmail.com
}

\begin{abstract}
The essence of Corporate Social Responsibility (CSR) in Indonesia is the corporate commitment to participate in sustainable economic development by donating its profits in portion and to improve the quality of life and the environment which is providing the benefits to both corporations and society in large. CSR is not merely granting charity as well as voluntary stewardship activity, yet in recent development has become a corporate obligation as stipulated in the Limited Liability Company. In the CSR donation, the corporate carried out in variety; firstly, it directly executed by the corporation, secondly, corporate initiative with other organization in partnership, such as local government. In practice, the mechanism of CSR donation supported by local government actually accomplished by different ways, i.e. implementing without the Regional Expenditure Budget (Anggaran Pendapatan Belanja Daerah, $A P B D$ ) or direct donation and donating by means of the APBD mechanism. If the CSR donation management paradoxically went against the rules such infringement and abuse of power implicated the actual loss, than this act obviously categorized as corruption. Otherwise, If this violation without going through the Regional Expenditure Budget (Anggaran Pendapatan Belanja Daerah, $A P B D)$, then the legal consequences would divide into two types: first, unlawful acts (onrechtmatigedaad) that classified within the jurisdiction of civil law and second is criminal offenses considered the jurisdiction of criminal law.
\end{abstract}

Keyword: CSR; Corporation; Corruption

Abstrak: Hakekat CSR adalah komitmen korporasi untuk berperan serta dalam pembangunan ekonomi berkelanjutan dengan menyumbangkan sebagian keuntungannya guna meningkatkan kualitas kehidupan dan lingkungan yang bermanfaat, baik bagi korporasi maupun masyarakat pada umumnya. CSR tidak hanya sekadar aktivitas kedermawanan (charity) atau aktivitas saling mengasihi 
(stewardship) yang bersifat sukarela, namun dalam perkembangannya di Indonesia menjadi suatu kewajiban korporasi sebagaimana tertuang UU Perseroan Terbatas. Dalam penyaluran CSR dilakukan secara bervariasi oleh korporasi, ada yang dilaksanakan langsung oleh korporasi, namun juga terkadang korporasi bermitra dengan pihak lain, seperti pemerintah daerah. Dalam praktiknya, prosedur penyaluran bantuan CSR oleh pemerintah daerah dilakukan dengan cara berbeda yaitu dengan tanpa mekanisme APBD (penyaluran langsung) dan penyaluran melalui mekanisme APBD. Bilamana CSR tersebut dalam penyaluran dan pengelolaannya terjadi suatu penyimpangan hukum seperti perbuatan melawan hukum atau penyalahgunaan wewenang yang berdampak pada terjadinya kerugian Negara atau daerah maka perbuatan tersebut dapat dikategorikan sebagai tindak pidana korupsi. Jika terjadi pelanggaran hukum dalam penyaluran dan pengelolaan CSR korporasi secara langsung tanpa melalui mekanisme APBD, maka implikasi hukumnya terbagi dua macam yaitu; perbuatan melanggar hukum yang masuk dalam wilayah hukum perdata dan tindak pidana umum yang masuk wilayah hukum pidana.

Kata kunci: CSR; Korporasi; Korupsi

\section{PENDAHULUAN}

Tujuan negara dalam Undang-Undang Dasar Negara Republik Indonesia 1945 (UUD NRI Tahun 1945) adalah mewujudkan kemakmuran dan kesejahteraan serta mewujudkan keadilan bagi rakyat. Hal ini sebagaimana diamanatkan oleh Konstitusi negara Indonesia yaitu dalam Pasal 33 ayat (3) UUD NRI 1945 menyatakan: "Bumi dan air dan kekayaan alam yang terkandung di dalamnya dikuasai oleh negara dan dipergunakan untuk sebesarbesarnya kemakmuran rakyat". Selain itu pula, tujuan negara sebagaimana tercantum dalam Alinea IV Pembukaan UUD NRI 1945 menyatakan: “..., dan untuk memajukan kesejahteraan umum,...".

Dalam hal peningkatan ekonomi dan pemanfaatan sumber daya alam serta perwujudan kesejahteraan masyarakat, pemerintah membutuhkan peran pihak-pihak lain. Salah satu cara yang dilakukan adalah melibatkan peran pelaku usaha atau pihak swasta. Salah satu cara untuk mengatasi persoalan sosial masyarakat tersebut adalah menciptakan regulasi tentang kewajiban bagi perusahaan untuk memberikan sebagian keuntungan perusahaan untuk masyarakat sekitar yang lebih dikenal dengan tanggung jawab sosial perusahaan atau lebih dikenal dengan Corporate Social Responsibility (CSR).

Istilah CSR di Indonesia diatur dalam UURI No.40 Tahun 2007 tentang Perseroan Terbatas atau lazimnya dikenal dengan Tanggung Jawab Sosial dan Lingkungan. Hal ini ditegaskan secara khusus dalam Pasal 74 yang menentukan bahwa perseroan yang 
menjalankan kegiatan di bidang dan/atau berkaitan dengan sumber daya alam wajib untuk melaksanakan tanggung jawab sosial dan lingkungan. Dengan demikian, CSR tersebut sesungguhnya ditujukan pada perusahaan yang melakukan kegiatan eksplorasi dan eksploitasi seperti halnya dibidang pertambangan, perminyakan, kehutanan dan perkebunan.

Persoalan penyaluran bantuan CSR oleh korporasi dalam dasawarsa terakhir masih menyisakan beberapa masalah khususnya terkait dengan kepastian dan dasar hukum. salah satu isu yang muncul adalah anggapan bilamana bantuan CSR dapat diserahkan secara langsung pada pemerintah daerah. Dalam ketentuan hukum di Indonesia, pelaksanaan CSR Korporasi dilaksanakan secara langsung oleh Korporasi yang bersangkutan kepada masyarakat atau lingkungan. Dalam praktik, adakalanya penyaluran CSR tidak secara langsung dilakukan oleh korporasi, akan tetapi meminta bantuan pemerintah daerah dalam menyalurkan CSR tersebut sehingga menimbulkan beragam cara yang dilakukan pemerintah dalam pelaksanaannya. Lebih lanjut, dalam prosesnya, ada yang menyalurkan secara langsung kepada masyarakat dan ada pula yang menyalurkan dengan cara Hibah kepada daerah melalui mekanisme APBD sebagai aset daerah. Penyaluran melalui pemerintah tersebut, ada yang berpandangan bahwa bila terjadi penyimpangan hukum, maka persoalan tersebut masuk ke dalam tindak pidana korupsi. Sebaliknya, bilamana terjadi pelanggaran hukum masuk ke dalam tindak pidana umum.

\section{METODE PENELITIAN}

Penelitian tersebut mengacu pada penelitian hukum (legal research). karakteristik penelitian hukum yakni mencari kebenaran koherensi yang mana suatu kebenaran didasarkan pada kesesuaian antara yang ditelaah dengan aturan yang ditetapkan. Pandangan ahli Peter Mahmud Marzuki mengatakan bahwa penelitian hukum adalah suatu proses untuk menemukan aturan hukum, prinsip-prinsip hukum, dan doktrindoktrin hukum guna menjawab isu hukum yang dihadapi. Hal tersebut sesuai dengan karakter preskriptif dari ilmu hukum ${ }^{1}$.

1 Peter Mahmud Marzuki, Penelitian Hukum, Jakarta: Kencana Prenada Media Group, 2005, hlm. 93. 


\section{ANALISIS DAN PEMBAHASAN}

\section{Konsep Tentang Corporate Social Responsibility}

John Elkingston ${ }^{2}$ memaparkan CSR dalam tulisannya berjudul Cannibals With Forks: the Triple Bottom Line of 21st Century Business sebagai berikut:

"Corporate Social Responsibility is a concept that organisation especially (but not only) employees, shareholders, communities, and ecological considerations in all aspect of their operations. This obligation is been to extend beyond their statutory obligation to comply with legislation".

Pandangan Archie B Carroll ${ }^{3}$ tentang CSR sebagai berikut:

Though the roots of the concept that we know today as corporate social responsibility have a long and wide-ranging history, it is mostly a product of the twentieth century, especially from the early 1950 s up to the present time. In spite of its recent growth and popularity, one can trace for centuries evidence of the business community's concern for society. To help appreciate the context in which corporate social responsibility (CSR) grew and flourished, we will consider the late 1800s, or the Industrial Revolution, as a reasonable beginning point for purposes of discussion.

Selain itu pula, David Crowther dan Güler Aras $^{4}$ mendefinisikan CSR sebagai berikut;

Definition of CSR;

The broadest definition of corporate social responsibility is concerned with what is or should be - the relationship between global corporations, governments of countries and individual citizens. More locally the definition is concerned with the relationship between a corporation and the local society in which it resides or operates. Another definition is concerned with the relationship between a corporation and its stakeholders.

For us all these definitions are pertinent and each represents a dimension of the issue. A parallel debate is taking place in the arena of ethics - should corporations be controlled through increased regulation or has the ethical base of citizenship been lost and needs replacing before socially responsible behaviour will ensue? However this debate is represented it seems that it is concerned with some sort of social contract between corporations and society.

2 John Elkington, “Cannibals With Forks: the Triple Bottom Line of 21st Century Business”, Journal of Business Ethics, Volume 23, Number 2, January 2000, Available from: http://www.springerlink.com/businessand-economics.

3 Archie B Carroll, "A History of Corporate Social Responsibility: Concepts and Practices”, dalam Andrew Crane dkk. (ed), The Oxford Handbook of Corporate Social Responsibility, Oxford: Oxford University Press, 2008.

4 David Crowther; Güler Aras, Op.Cit, p. 11 
Pemikiran Michael Fontaine ${ }^{5}$ mengutarakan tujuan CSR adalah mencakup kegiatan korporasi dan mendorong pengaruh positif melalui kegiatannya terhadap lingkungan, konsumen, karyawan, masyarakat, pemangku kebijakan, dan semua pihak lainnya atas bidang lingkungan. Selanjutnya, CSR memfokuskan pada kegiatan bisnis yang secara proaktif memperkenalkan kepentingan publik dengan mendorong pertumbuhan masyarakat dan pengembangan, serta secara sukarela menghilangkan praktik-praktik yang dapat membahayakan dibidang lingkungan, terlepas dari legalitas. CSR merupakan kegiatan yang melibatkan kepentingan publik ke dalam pembuatan kebijakan korporasi, dan menghormati konsep Triple Bottom Line (TBL atau 3P); masyarakat, planet, keuntungan (people, planet, profit).

Dalam pandangan yang lain, tujuan CSR menurut McOliver-EA Marshal dalam Yahya Harahap ${ }^{6}$ mengemukakan CSR bertujuan, antara lain;

1. Memberikan sebagian keuntungan perseroan kepada masyarakat dan lingkungan;

2. Melibatkan sumber dan personal perseroan mengadakan pelatihan khusus (special training) dan kegiatan non laba (non-profit) kepada masyarakat sekitarnya;

3. Ikut bertanggungjawab melindungi lingkungan (environmental protection) di sekitarnya.

Jika dikelompokkan, sedikitnya ada empat manfaat CSR terhadap korporasi:

1) Brand differentiation. Dalam persaingan pasar yang kian kompetitif, CSR bisa memberikan citra perusahaan yang khas, baik, dan etis dimata publik yang pada gilirannya menciptakan customer loyalty. The Body Shop sering dianggap sebagai memiliki image unik terkait isu lingkungan.

2) Human resources. Program CSR dapat membantu dalam perekrutan karyawan baru, terutama yang memiliki kualifikasi tinggi. Saat interviu, calon karyawan yang memiliki pendidikan dan pengalaman yang tinggi sering bertanya tentang CSR dan etika bisnis perusahaan, sebelum mereka memutuskan menerima tawaran. Bagi staf lama, CSR juga dapat meningkatkan persepsi, reputasi, dan motivasi dalam kerja.

3) License to operate. Perusahaan yang menjalankan CSR dapat mendorong pemerintah dan publik memberi "izin" atau "restu" bisnis. Karena dianggap telah memenuhi standar operasi dan kepedulian terhadap lingkungan dan masyarakat luas.

4) Risk management. Manajemen risiko merupakan isu sentral bagi setiap perusahaan. Reputasi perusahaan yang dibangun bertahun-tahun bisa runtuh dalam sekejap oleh skandal korupsi, kecelakaan karyawan dan kerusakan lingkungan. BP dengan bendera "Beyond Petroleum"-nya pernah disanjung

5 Michael Fontaine, "Corporate Social Responsibility and Sustainability: The New Bottom Line?", International Journal of Business and Social Science Vol. 4 No. 4; April, 2013, p. 2

6 Yahya Harahap, Loc. Cit, hlm. 299 
sebagai perusahaan "ramah lingkungan". Namun, pencemaran di teluk Mexico AS telah meruntuhkan image tersebut. Membangun budaya "doing the right thing" berguna bagi perusahaan dalam mengelola risiko-risiko bisnis7 .

CSR merupakan kewajiban asasi perusahaan yang tidak boleh dihindari. Dasar argumentasinya adalah teori akuntabilitas korporasi (corporate acuntability theory). Menurut teori ini, perusahaan harus bertanggung jawab atas semua konsekuensi yang ditimbulkan baik sengaja maupun tidak sengaja kepada para pemangku kepentingan (stakeholders) ${ }^{8}$.

Secara khusus, teori tersebut menyatakan CSR tidak hanya sekadar aktivitas kedermawanan (charity) atau aktivitas saling mengasihi (stewardship) yang bersifat sukarela kepada sesama seperti dipahami para pebisnis selama ini, tetapi juga harus dipahami sebagai suatu kewajiban asasi yang melekat dan menjadi "roh kehidupan" dalam sistem serta praktik bisnis. Alasannya, CSR merupakan konsekuensi logis dari adanya hak asasi yang diberikan negara kepada perusahaan untuk hidup dan berkembang dalam suatu area lingkungan. jika tidak ada keselarasan antara hak dan kewajiban asasi perusahaan, dalam area tersebut akan hidup dua pihak, yaitu gainers (perusahaan) dan losers yaitu masyarakat. ${ }^{9}$

Namun pelaksanaan CSR di Indonesia menimbulkan pertanyaan yaitu korporasi yang bagaimanakah yang dibebani kewajiban CSR? Untuk menjawab pertanyaan ini ditemukan dalam Pasal 74 ayat (1) dan (2) Undang-Undang Nomor 40 Tahun 2007 tentang Perseroan Terbatas menyatakan bahwa perseroan yang menjalankan kegiatan usahanya di bidang dan/atau berkaitan dengan SDA, wajib melaksanakan Tanggung Jawab Sosial dan Lingkungan (TJSL) yang dianggarkan dan diperhitungkan sebagai biaya Perseroan.

Terkait dengan kewajiban korporasi yang melaksanakan CSR, Pasal 3 Peraturan Pemerintah Nomor 47 Tahun 2012 tentang Tanggung Jawab Sosial dan Lingkungan, memberikan penegasan bahwa Perseroan (Korporasi) yang kegiatan usahanya di bidang dan/atau berkaitan dengan sumber daya alam diwajibkan untuk melaksanakan tanggung jawab sosial dan lingkungan.

7 Edi Suharto, SCR \& COMDEV Investasi Kreatif Perusahaan Di era Globalisasi, Bandung: Alfabeta, 2010, hlm. 52-53.

8 Andreas Lako, Dekonstruksi CSR \& Reformasi Paradigma Bisnis \& Akuntansi, Jakarta: Penerbit Erlangga, 2011, hlm. 5.

9 Ibid. 


\section{CSR Yang Berimplikasi Tindak Pidana Korupsi}

Dalam pelaksanaan CSR sedikitnya ada 4 (empat) model atau pola CSR yang umumnya diterapkan oleh perusahaan di Indonesia, yaitu ${ }^{10}$ :

1) Keterlibatan langsung. Perusahaan menjalankan program CSR secara langsung dengan menyelenggarakan sendiri kegiatan sosial atau menyerahkan sumbangan ke masyarakat tanpa perantara. Untuk menjalankan tugas ini, sebuah perusahaan biasanya menugaskan salah satu pejabat seniornya, seperti corporate secretary atau public affair manager atau menjadi bagian dari tugas pejabat public relation.

2) Melalui yayasan atau organisasi sosial perusahaan. Perusahaan mendirikan yayasan sendiri di bawah perusahaan atau grupnya. Model ini merupakan adopsi dari model yang lazim diterapkan di perusahaan-perusahaan di negara maju. Biasanya, perusahaan menyediakan dana awal, dana rutin atau dana abadi yang dapat digunakan secara teratur bagi kegiatan yayasan. Beberapa yayasan yang didirikan perusahaan di antaranya adalah Yayasan Coca-Cola Company, Yayasan Rio Tinto (perusahaan pertambangan), Yayasan Dharma Bhakti Astra, Yayasan Sahabat Aqua, GE Fund.

3) Bermitra dengan pihak lain. Perusahaan menyelenggarakan CSR melalui kerja sama dengan lembaga sosial/organisasi non-pemerintah (NGO/LSM), instansi pemerintah, universitas atau media massa, baik dalam mengelola dana maupun dalam melaksanakan kegiatan sosialnya. Beberapa lembaga sosial/Ornop yang bekerja sama dengan perusahaan dalam menjalankan CSR antara lain adalah Palang Merah Indonesia (PMI), Yayasan Kesejahteraan Anak Indonesia (YKAI), Dompet Dhuafa; instansi pemerintah (Lembaga Ilmu Pengetahuan Indonesia/LIPI, Depdiknas, Depkes, Depsos); universitas (UI, ITB, IPB); media massa (DKK Kompas, Kita Peduli Indosiar).

4) Mendukung atau bergabung dalam suatu konsorsium. Perusahaan turut mendirikan, menjadi anggota atau mendukung suatu lembaga sosial yang didirikan untuk tujuan sosial tertentu. Dibandingkan dengan model lainnya, pola ini lebih berorientasi pada pemberian hibah perusahaan yang bersifat "hibah pembangunan". Pihak konsorsium atau lembaga semacam itu yang dipercayai oleh perusahaan-perusahaan yang mendukungnya secara pro aktif mencari mitra kerja sama dari kalangan lembaga operasional dan kemudian mengembangkan program yang disepakati bersama.

Jika di analisa model-model penyaluran CSR di atas, tampak adanya menyinggung keterlibatan instansi pemerintah dalam penyaluran CSR. Hal tersebut dapat dilihat bahwa pemerintah saat ini berperan aktif dalam penyaluran dan pengelolaan CSR korporasi. Latar belakang peran pemerintah tersebut dilandasi oleh pandangan bahwa pemerintahlah yang memahami secara umum kondisi dan geografi daerah serta masyarakat yang layak menerima bantuan CSR (tepat sasaran). Dasar pemikiran tersebut

10 Saidi Zaim dan Hamid Abidin, Menjadi Bangsa Pemurah: Wacana dan Praktek Kedermawanan Sosial di Indonesia, Jakarta: Piramida, 2004, hlm. 32. 
dapat digambarkan melalui beberapa contoh pemerintah daerah yang berperan aktif dalam membantu dan menyalurkan CSR korporasi seperti halnya pada Provinsi Daerah Khusus Ibukota Jakarta (DKI) yang membangun jalan simpang susun Semanggi yang dananya bersumber dari CSR pihak swasta sebagai Kompensasi Lantai Bangunan (KLB) ${ }^{11}$. Contoh lainnya adalah dua infrastruktur yakni pembangunan jembatan gantung dan stadion sepak bola yang mana sumber pembiayaannya berasal dari CSR korporasi PT Wiratman. Dari contoh penyaluran CSR tersebut, dapat dimaknai bahwa hendaknya program tersebut telah disesuaikan dengan rencana kerja tahunan korporasi.

Terkadang dalam praktik penyaluran bantuan CSR sering dipandang adanya keharusan selalu dilaksanakan langsung suatu korporasi, hal ini dilandasi bahwa ketentuan hukum mengenai CSR dalam PP No.47 Tahun 2012 tentang Tanggung Jawab Sosial dan Lingkungan Perseroan Terbatas. Akan tetapi ketentuan tersebut jika dikaitkan konsep CSR dalam perkembangannya mengalami perubahan dimana pemerintah dilibatkan oleh korporasi dalam penyaluran dan pengelolaan CSR. Dalam kaitannya dengan keterlibatan pemerintah dalam penyaluran dan pengelolaan CSR melahirkan berbagai pandangan. Ada yang berpendapat bahwa pemerintah tidak dapat terlibat dalam proses penyaluran dan pengelolaan CSR. Disisi lain, terdapat pendapat bahwa pemerintah dapat terlibat dalam proses dan penyaluran CSR.

Pandangan penulis, peran aktif pemerintah dalam proses dan penyaluran CSR sesungguhnya dapat dilakukan dengan pemikiran dasar berupa:

a) Makna CSR adalah komitmen korporasi untuk berperan serta dalam pembangunan ekonomi berkelanjutan dengan menyumbangkan sebagian keuntungannya guna meningkatkan kualitas kehidupan dan lingkungan yang bermanfaat, baik bagi korporasi maupun masyarakat pada umumnya. Dari makna tersebut sesungguhnya memberikan gambaran yang jelas bila CSR tidaklah mempermasalahkan proses penyalurannya, apakah dilakukan secara langsung oleh korporasi atau melalui perantara pihak lain termasuk pemerintah.

b) Pemerintah mempunyai peran aktif dalam bidang sosial yang bertujuan menyejahterakan masyarakat. Hal tersebut tertuang dalam ketentuan hukum yang mengatur adanya urusan pemerintahan wajib yang berkaitan dengan pelayanan dasar adalah dibidang sosial. Ketika terdapat inisiatif korporasi untuk meminta bantuan pemerintah dalam rangka menyalurkan CSR korporasi, maka secara hukum pemerintah dapat berperan aktif dengan pertimbangan

11 Jessi Carina, Simpang Susun Semanggi yang Dimulai Ahok, Diselesaikan Djarot, dan Akan Diresmikan Jokowi..., Kompas.com, h https://megapolitan.kompas.com/read/2017/08/17/19341831/tanpabanyak-kata-jokowi-resmikan-simpang-susun-semanggi-, diakses pada tanggal 19 Desember 2017 
selain menjadi urusan Pemerintah juga pemerintah daerah yang memahami kondisi wilayah dan masyarakat (tepat sasaran).

Dengan adanya CSR yang merupakan kewajiban korporasi sebagai tanggung jawab sosial dan lingkungan, maka bilamana penyaluran dan pengelolaan CSR dilakukan oleh pemerintah, maka hal tersebut merupakan cara alternatif yang harus dipahami sebagai permintaan (inisiatif) korporasi tersebut. Dengan demikian, keterlibatan pemerintah ini adalah inisiatif atau permintaan dari korporasi. Hal ini sangat rasional dengan alasan bahwa saat ini korporasi sering menghadapi kendala-kendala internal korporasi tersebut seperti halnya keterbatasan sumber daya manusia dan lain sebagainya.

Dalam praktiknya, prosedur penyaluran bantuan CSR ini dilakukan dengan cara berbeda oleh pemerintah daerah yaitu dengan tanpa mekanisme APBD (penyaluran langsung) dan penyaluran melalui mekanisme APBD. Prosedur tanpa mekanisme APBD adalah penyaluran langsung kepada masyarakat melalui instansi teknis perangkat daerah tanpa harus memasukkan CSR tersebut ke dalam APBD. Hal ini sebagai dasar pembenaran kuasa korporasi kepada pemerintah daerah. Salah satu contohnya bantuan CSR melalui APBD ini dapat dilihat pada bantuan Rumah Susun Sederhana Sewa (RUSUNAWA) Marunda Jakarta. Bantuan ini berupa perabot rumah tangga yang berasal dari 18 korporasi melalui Dinas Sosial Jakarta Utara ${ }^{12}$.

Sedangkan mekanisme melalui APBD yakni sebelum penyaluran dan pengelolaan bantuan CSR dilakukan oleh pemerintah daerah, terlebih dahulu dilakukan dengan mekanisme hibah oleh korporasi kepada pemerintah yang dituangkan dalam Naskah perjanjian Hibah daerah (NPHD), kemudian CSR tersebut dituangkan dalam APBD. Setelah dituangkan dalam APBD dan dicatat sebagai pendapatan hibah dalam kelompok Lain-lain Pendapatan yang sah pada APBD sebagai keuangan daerah, kemudian CSR tersebut dilaksanakan sesuai mekanisme perundang-undangan yang berlaku. Adapun landasan hukum mekanisme keterlibatan pemerintah dalam proses dan penyaluran CSR yang dilakukan melalui akta hibah sebagaimana diatur dalam Pasal 1 angka 7 dan 8 Peraturan Pemerintah Republik Indonesia Nomor 57 Tahun 2005 Tentang Hibah Kepada Daerah. Adapun ketentuan angka 7 dan 8 menyebutkan bahwa;

(7) Hibah adalah Penerimaan Daerah yang berasal dari pemerintah negara asing, badan/lembaga asing, badan/lembaga internasional, pemerintah,

12 Nurul Julaikah, Ini CSR untuk Dinas Perumahan yang dikelola Ahok Center, Merdeka.com, https://www.merdeka.com/jakarta/ini-csr-untuk-dinas-perumahan-yang-dikelola-ahok-center.html, diakses pada tanggal 9 Januari 2018. 
badan/lembaga dalam negeri atau perorangan, baik dalam bentuk devisa, rupiah maupun barang dan atau jasa, termasuk tenaga ahli dan pelatihan yang tidak perlu di bayar kembali.

(8) Naskah Perjanjian Hibah Daerah, selanjutnya disingkat NPHD adalah naskah perjanjian hibah antara pemberi hibah yang berasal dari dalam negeri dan Pemerintah Daerah.

Selanjutnya dalam Pasal 2 ayat (2) mengenai pemberian hibah. Selengkapnya ditentukan dalam pasal tersebut adalah;

Hibah dari Dalam Negeri sebagaimana dimaksud pada ayat (1) huruf a bersumber dari:

a. Pemerintah;

b. Pemerintah Daerah lain;

c. Badan/lembaga/organisasi swasta dalam negeri; dan/atau

d. Kelompok masyarakat/perorangan.

Namun dalam kelanjutannya ketentuan mengenai hibah kepada pemerintah daerah tersebut telah mengalami perubahan dengan terbitnya PP No. 2 Tahun 2012 Tentang Hibah Daerah. Dalam ketentuan baru ini disebutkan beberapa ketentuan antara lain;

- Pasal 2 huruf a;

Hibah Daerah meliputi: (a) Hibah kepada Pemerintah Daerah;

- Pasal 3;

Hibah Daerah dapat berbentuk uang, barang, dan/atau jasa.

- Pasal 4 ayat (1) huruf b dan c;

Hibah kepada Pemerintah Daerah sebagaimana dimaksud dalam Pasal 2 hurufa dapat berasal dari: (b). badan, lembaga, atau organisasi dalam negeri; dan/atau (c). kelompok masyarakat atau perorangan dalam negeri.

Terdapat pula aturan hukum lainnya terkait dengan hibah pemerintah daerah yakni Berdasarkan PMK Nomor 168/PMK.07/2008 tentang Hibah Daerah, adapun ketentuan sebagai berikut;

- Pasal 1 angka 11;

Hibah Daerah adalah bantuan dari Pemerintah atau pihak lain kepada Pemerintah Daerah atau sebaliknya yang tidak perlu dibayar kembali.

- Pasal 2 ayat (1) huruf a;

Hibah Daerah meliputi: a. Hibah kepada Pemerintah Daerah.

- Pasal 2 ayat (2);

Hibah sebagaimana dimaksud pada ayat (1) dapat berbentuk uang, barang, dan/atau jasa. 
- Pasal 2 ayat (3) huruf c;

Hibah kepada Pemerintah Daerah sebagaimana dimaksud pada ayat (1) hurufa dapat bersumber dari: c. Badan/lembaga/organisasi swasta dalam negeri; dan/atau

- Pasal 3 ayat (1);

Hibah sebagaimana dimaksud dalam Pasal 2 ayat (3) huruf b, huruf c dan huruf $d$ dikelola dan dilaksanakan dalam mekanisme APBD sesuai dengan peraturan perundang-undangan.

- Pasal 14 ayat (1);

NPHD atau NPPH sebagaimana dimaksud dalam pasal 13 ayat (1) paling kurang memuat ketentuan mengenai:
a. Tujuan hibah;
b. Jumlah hibah;
c. Sumber hibah;
d. Penerima hibah;
e. Persyaratan hibah;
f. Tata cara penyaluran hibah;
g. Tata cara penggunaan hibah;
h. Tata cara pelaporan dan pemantauan hibah;
i. Hak dan kewajiban pemberi dan penerima hibah; dan
j. Sanksi.

- Pasal 19;

(1) Dalam hal Pemerintah Daerah menerima hibah dari Pemerintah Daerah lain, Badan/lembaga/organisasi swasta dalam negeri, dan/atau Kelompok masyarakat/perorangan dalam negeri sebagaimana dimaksud dalam Pasal 2 ayat (3) hurufb, huruf c dan hurufd, hibah dimaksud dituangkan dalam NPHD yang dibuat dan ditandatangani oleh Pemerintah Daerah dengan pemberi hibah.

(2) Copy NPHD sebagaimana dimaksud pada ayat (1) disampaikan oleh Pemerintah Daerah penerima hibah kepada Menteri Keuangan cq. Direktur Jenderal dan instansi terkait.

- Pasal 23 ayat (1);

Penerimaan hibah oleh Pemerintah Daerah dicatat sebagai pendapatan hibah dalam kelompok Lain-lain Pendapatan yang Sah pada APBD.

Selain tersebut di atas, terdapat aturan hukum lainnya antara lain Peraturan Pemerintah Republik Indonesia Nomor 58 tahun 2005 Tentang Pengelolaan Keuangan

Daerah. Dalam aturan ini yaitu Pasal 24 dan 25, adalah sebagai berikut;

- Pasal 24;

Lain-lain pendapatan daerah yang sah merupakan seluruh pendapatan daerah selain PAD dan dana perimbangan, yang meliputi hibah, dana darurat, dan lainlain pendapatan yang ditetapkan pemerintah. 
- Pasal 25;

(1) Hibah sebagaimana dimaksud dalam Pasal 24 merupakan bantuan berupa uang, barang, dan/atau jasa yang berasal dari pemerintah, masyarakat, dan badan usaha dalam negeri atau luar negeri yang tidak mengikat.

(2) Ketentuan lebih lanjut mengenai hibah sebagaimana dimaksud pada ayat (1) diatur dalam peraturan perundangan tersendiri.

Mekanisme penyaluran dan pengelolaan yang melalui APBD, contohnya dapat dilihat pada Gubernur Sulawesi Tengah yang menerima bantuan dana CSR dari P.T Vale, Tbk. Dana CSR yang senilai Rp 11,7 Miliar kemudian dimasukkan ke dalam bentuk Hibah Daerah yang selanjutnya dituangkan APBD Perubahan 2016 sebelum didistribusikan ke SKPD ${ }^{13}$

Dalam penyaluran CSR, kadang kala dijumpai suatu problem dimana korporasi belum mampu menyalurkan bantuan CSR secara mandiri. Hal ini dapat diukur dari beberapa parameter antara lain;

1) Tidak semua korporasi memiliki sumber daya manusia yang memadai untuk menjalankan distribusi CSR;

2) Tidak semua korporasi memahami kebutuhan masyarakat di suatu daerah;

3) Orientasi korporasi yang lebih mengutamakan keuntungan (benefit) dari pada kepentingan masyarakat.

Dalam rangka mengantisipasi problem yang dihadapi oleh korporasi, maka seyogyanya korporasi membutuhkan peran pemerintah membantu penyaluran CSR. Argumentasi ini dilandasi oleh;

1) Pemerintah daerah yang memahami kondisi wilayah dan masyarakat yang layak menerima bantuan CSR;

2) Pemerintah daerah memiliki sumber daya manusia yang memadai dengan melibatkan beberapa Satuan Perangkat Daerah (SKPD) berdasarkan bidangnya.

3) Sebagai bentuk implementasi dari undang-undang otonomi daerah khususnya yang terkait dengan pelayanan dasar sosial.

4) Terciptanya sinkronisasi antara bantuan CSR dan program pemerintah daerah.

Adanya cara yang ditempuh dalam proses penyaluran CSR melalui Pemerintah tersebut disalurkan melalui Hibah kepada Pemerintah daerah yang dituangkan dalam Naskah Perjanjian Hibah Daerah, maka dapat dikategorikan CSR tersebut sebagai sumber penerimaan/pendapatan pemerintah. Dengan adanya sumber penerimaan pemerintah

13 Amar Burase, Kasus Dana CSR di Sulteng, Ini Penjelasan PT Vale Indonesia, Tempo, https://nasional.tempo.co/read/827568/kasus-dana-csr-di-sulteng-ini-penjelasan-pt-vale-

indonesia/full\&view=ok, diakses pada tanggal 9 Januari 2018. 
tersebut, maka pengelolaannya haruslah berlandaskan pada ketentuan hukum pengelolaan keuangan negara/daerah, seperti dicatat dalam daftar aset pemerintah dan proses penyalurannya melalui mekanisme APBD.

Dari hal tersebut, menurut penulis parameter hukum untuk menentukan CSR termasuk kategori keuangan negara atau daerah adalah:

1. CSR korporasi tersebut dihibahkan pada pemerintah daerah yang ditandai dengan dituangkannya dalam Naskah Perjanjian Hibah Daerah (NPHD) antara pemerintah daerah dengan korporasi;

2. Kemudian CSR tersebut dituangkan dalam APBD dan dicatat sebagai pendapatan hibah dalam kelompok Lain-lain Pendapatan yang sah pada APBD sebagai keuangan daerah.

Dari konstruksi hukum tersebut, maka CSR korporasi tersebut melebur menjadi keuangan negara atau daerah, sehingga penyaluran dan pengelolaannya walaupun disesuaikan dengan program rencana kerja korporasi, akan tetapi prosesnya haruslah dilakukan dengan mekanisme perundang-undangan yang berlaku sebagaimana layaknya keuangan negara atau daerah. Kedua hal tersebut merupakan pintu masuk untuk CSR dikategorikan sebagai keuangan negara.

Bilamana CSR tersebut dalam penyaluran dan pengelolaannya terjadi suatu penyimpangan hukum seperti perbuatan melawan hukum atau penyalahgunaan wewenang yang berdampak pada terjadinya kerugian negara atau daerah maka perbuatan tersebut dapat dikategorikan sebagai tindak pidana korupsi.

Sebaliknya jika terjadi pelanggaran hukum dalam penyaluran dan pengelolaan CSR korporasi secara langsung tanpa melalui mekanisme APBD, maka implikasi hukumnya terbagi dua macam yaitu; perbuatan melanggar hukum yang masuk dalam wilayah hukum perdata dan tindak pidana umum yang masuk wilayah hukum pidana. Dengan demikian, pelanggaran hukum dalam penyaluran dan pengelolaan CSR oleh pemerintah daerah mempunyai akibat hukum yang berbeda-beda.

\section{KESIMPULAN}

Berdasarkan hasil pembahasan isu hukum sebagaimana yang telah diuraikan pada bagian sebelumnya, maka dirumuskan kesimpulan sebagai berikut;

1. Pada hakikatnya CSR adalah pemberian sebagian keuntungan korporasi yang di peruntukkan bagi kepentingan masyarakat dan lingkungan. Selain itu, pada prinsipnya yang dituju oleh CSR adalah bagaimana kepentingan masyarakat dan 
lingkungan tercapai, dan bukan pada proses penyalurannya. Terkait proses penyaluran kewajiban CSR dapat dilakukan melalui; (a) Langsung kepada masyarakat; (b) Pemerintah dengan beberapa persyaratan; (i) Permintaan Korporasi, (ii) Sesuai dengan rencana kerja Korporasi, dan (iii) CSR menyangkut fasilitas publik yang tidak dapat dilaksanakan sendiri oleh Korporasi. Contohnya, pembuatan jalanan, rumah sakit, stadion olah raga, dan lain sebagainya.

2. Parameter hukum untuk menentukan CSR termasuk kategori keuangan negara atau daerah adalah; (1) CSR korporasi tersebut dihibahkan pada pemerintah daerah yang ditandai dengan dituangkannya Naskah Perjanjian Hibah Daerah (NPHD) antara pemerintah daerah dengan korporasi; (2) CSR tersebut dituangkan dalam APBD dan dicatat sebagai pendapatan hibah dalam kelompok Lain-lain Pendapatan yang sah pada APBD sebagai keuangan daerah. Kedua hal tersebut merupakan pintu masuk untuk CSR dikategorikan sebagai keuangan negara. Bilamana CSR tersebut dalam penyaluran dan pengelolaannya terjadi suatu perbuatan melawan hukum atau penyalahgunaan wewenang yang berdampak pada terjadinya kerugian negara atau daerah, maka perbuatan tersebut dapat dikategorikan sebagai tindak pidana korupsi.

Berdasarkan kesimpulan sebagaimana telah dirumuskan di atas, dapat di tarik suatu rekomendasi adalah sebagai berikut;

1. Perlunya disusun suatu panduan hukum CSR yang mereposisikan secara jelas peran Pemerintah atau Pemerintah Daerah dalam penyaluran CSR, jika korporasi tidak dapat melaksanakan sendiri CSR-nya kemudian meminta bantuan pada Pemerintah atau Pemerintah Daerah untuk menyalurkannya.

2. Perlunya CSR yang diserahkan kepada Pemerintah Daerah dalam bentuk barang dan bukan dalam bentuk uang, untuk mencegah terjadinya tindak pidana korupsi

\section{Daftar Pustaka}

\section{Buku dan Jurnal}

Crane, Andrew dkk. (ed), The Oxford Handbook of Corporate Social Responsibility, Oxford: Oxford University Press, 2008. 
Elkington, John, “Cannibals With Forks: the Triple Bottom Line of 21st Century Business". Journal of Business Ethics, Volume 23, Number 2, 2000. Available from: http://www springerlink.com/business-and-economics.

Fontaine, Michael, “Corporate Social Responsibility and Sustainability: The New Bottom Line?” International Journal of Business and Social Science Vol. 4 No. 4; April, 2013.

Marzuki, Peter Mahmud, Penelitian Hukum, Jakarta: Kencana Prenada Media Group, 2005.

Lako, Andreas, Dekonstruksi CSR \& Reformasi Paradigma Bisnis \& Akuntansi, Jakarta: Penerbit Erlangga, 2011.

Suharto, Edi, SCR \& COMDEV Investasi Kreatif Perusahaan Di era Globalisasi, Bandung: Alfabeta, 2010.

Zaim, Saidi dan Hamid Abidin, Menjadi Bangsa Pemurah: Wacana dan Praktek Kedermawanan Sosial di Indonesia, Jakarta: Piramida, 2004.

\section{Internet}

Burase, Amar, Kasus Dana CSR di Sulteng, Ini Penjelasan PT Vale Indonesia, Tempo, https://nasional.tempo.co/read/827568/kasus-dana-csr-di-sulteng-inipenjelasan-pt-vale-indonesia/full\&view=ok, diakses pada tanggal 9 Januari 2018.

Carina, Jessi, Simpang Susun Semanggi yang Dimulai Ahok, Diselesaikan Djarot, dan Akan Diresmikan Jokowi..., Kompas.com, https://megapolitan.kompas.com/read/2017/ 08/17/19341831/tanpa-banyak-kata-jokowi-resmikan-simpang-susunsemanggi-, diakses pada tanggal 19 Desember 2017.

Julaikah, Nurul, Ini CSR untuk Dinas Perumahan yang dikelola Ahok Center, Merdeka.com, https://www.merdeka.com/jakarta/ini-csr-untuk-dinas-perumahan-yangdikelola-ahok-center.html, diakses pada tanggal 9 Januari 2018. 